(c) Group of authors, 2019

UDC 611.41-018:616.155.194

DOI - https://doi.org/10.14300/mnnc.2019.14106

ISSN - 2073-8137

\title{
CONTENT OF B- AND T-CELLS IN THE SPLEEN OF PATIENTS WITH APLASTIC ANEMIA
}

\author{
Fedorovskaya N. S. ${ }^{1}$, Petrov S. V. ${ }^{2}$, Zaitsev V. B. ${ }^{1}$ \\ ${ }^{1}$ Kirov State Medical University, Russian Federation \\ ${ }^{2}$ Kazan State Medical University, Russian Federation
}

\section{СОАЕРЖАНИЕ В - И Т-КАЕТОК В СЕАЕЗЕНКЕ ПАЦИЕНТОВ С АПААСТИЧЕСКОЙ АНЕМИЕЙ}

\author{
Н. С. Фелоровская ${ }^{1}$, С. В. Петров ${ }^{2}$, В. Б. Зайцев ${ }^{1}$ \\ 1 Кировский госуАарственный МеАицинский университет, Российская ФеАерация \\ ${ }^{2}$ Казанский госуАарственный меАицинский университет, Российская ФеАерация
}

\begin{abstract}
Using histological, immunohistochemical (IHC) and morphometric methods, B- and T-cells, we studied the spleens of 30 patients with aplastic anemia (AA). The median age is $21.0(18.5 ; 38.5)$ years. The control group consisted of 20 persons who died suddenly and who did not have a history of blood diseases. In the histological material of the spleens, with IHC staining and morphometry, the relative numerical values of B-cells and T-cells populations in the functional areas of the organ in AA patients were obtained. Recalculation of morphometric parameters in absolute values $(\mathrm{g})$ taking into account the mass of the spleen was carried out according to the original methodology. Evaluation of the content of B- and T-cells in the spleen made it possible to determine the factors predicting the course of development of AA after splenectomy. Signs which determine the unfavorable prognosis for the progression of disease are as follows: the absolute number of $\mathrm{CD}^{+} \mathrm{T}$-cells in the spleen is less than $5.4 \mathrm{~g}$ and the Mass Ratio Index (MRI) $\mathrm{CD} 4^{+} / \mathrm{CD} 8^{+} \mathrm{T}$-cells is less than or equal to 1.0. Consequentially that justifies a need for an individual approach to further immunosuppressive therapy in this category of patients.
\end{abstract}

Keywords: human spleen, B-cells, T-cells, aplastic anemia

На основании гистологических, иммуногистохимических и морфометрических методов изучали В- и Т-клетки в селезенке 30 больных с апластической анемией (AA). Медиана возраста - 21,0 $(18,5 ; 38,5)$ лет. Группу сравнения составили 20 лиц, скончавшихся скоропостижно и не имевших в анамнезе заболеваний системы крови. В гистологическом материале селезенок при ИГХ окрашивании и морфометрии получены численные значения популяций В- и Т-клеток в функциональных зонах органа у больных АА. Пересчет морфометрических показателей в абсолютные значения (г) с учетом массы селезенки проводился по оригинальной методологии. Оценка содержания В-и Т-клеток в селезенке позволила определить факторы прогноза течения АА после спленэктомии. Определяющими неблагоприятный прогноз признаками содержания клеточных субпопуляций в селезенке явились: значение абсолютного количества $\mathrm{CD} 4^{+}$Т-клеток в селезенке менее 5,4 г и величина индекса соотношения масс $\mathrm{CD}^{+} / \mathrm{CD} 8^{+} \mathrm{T}$-лимфоцитов меньше или равно 1,0, что обосновывает индивидуальный подход к проведению дальнейших курсов иммуносупрессивной терапии у данной категории больных.

Ключевые слова: селезенка человека, В-клетки, Т-клетки, апластическая анемия

For citation: Fedorovskaya N. S., Petrov S. V., Zaitsev V. B. CONTENT OF B- AND T-CELLS IN THE SPLEEN OF PATIENTS WITH APLASTIC ANEMIA. Medical News of North Caucasus. 2019;14(3):439-442. DOI - https://doi.org/10.14300/mnnc.2019.14106

Для цитирования: Федоровская Н. С., Петров С. В., Зайцев В. Б. СОДЕРЖАНИЕ В- и Т-КЛЕТОК В СЕЛЕЗЕНКЕ ПАЦИЕНТОВ С АПЛАСТИЧЕСКОЙ АНЕМИЕЙ. МедицинскиЙ вестник Северного Кавказа. 2019;14(3):439-442. DOI - https://doi.org/10.14300/mnnc.2019.14106

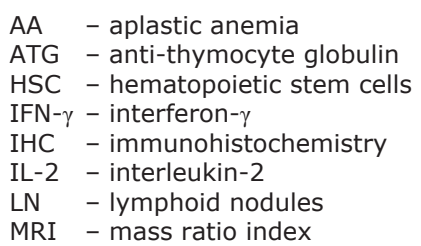


T he immune mechanisms of the development of aplastic anemia (AA) include the effects of cytotoxic T-cells on hematopoietic stem cells (HSC). Mediators of immune aggression of hematopoiesis: interferon- $\gamma$ (IFN- $\gamma$ ), tumor necrosis factor- $\alpha$ (TNF- $\alpha$ ), interleukin-2 (IL-2) lead to disruption of proliferation processes and stimulation of apoptosis of hematopoietic progenitors and stem cells, ultimately resulting in a marked decrease in the pool of hematopoietic cells and the development of bone marrow aplasia [1, 2].

The removal of a large mass of activated lymphoid cells involved in the genesis of the pathological process is one of the mechanisms of the influence of splenectomy on the course of AA. Splenectomy is included in the treatment program for adult $A A$ patients in case of intolerance to antithymocytic globulin (ATG) and if patients fail to respond to the first or second stage of immunosuppressive therapy of ATG for 3-6 months [3]. However, data on the quantitative content of lymphocytes in the spleen of patients with $\mathrm{AA}$, depending on the severity of the disease, have not been found. To study the cellular composition in histological sections of the spleen, we carried out investigations using modern technologies, such as immunohistochemistry (IHC) and computer morphometry.

The objective of the research was to determine the content of B- and T-cells in the spleen of patients with aplastic anemia.

Material and Methods. A study of the spleen was performed in 30 patients with AA. The median age was $21.0(18.5 ; 38.5)$ years. The number of male patients was $22(73.3 \%)$, female $-8(26.7 \%)$. Twelve patients (40\% out of total) had a form of nonsevere aplastic anemia (nSAA); 18 patients (60\% out of total) had a form severe aplastic anemia (SAA). All patients received complex treatment before splenectomy, including the introduction of methylprednisolone, cyclosporin-A. Splenectomy was performed on the $4^{\text {th }}-7^{\text {th }}$ day after initiation of glucocorticosteroid therapy. A comparative analysis was performed with the samples of the spleens, which were taken from 20 individuals who died suddenly and did not have diseases of blood. The median age was $39(36.3 ; 50.5)$ years. There were $12(60.0 \%)$ men and $8(40.0 \%)$ women.

Histological studies of the spleen were performed on sections from paraffin blocks (hematoxylin and eosin staining); IHC staining - with antibodies (CD20 CD3; CD4; CD8) and imaging system En VISION, PEROXIDASE (DAB) «Dako» in working dilutions. Morphometric results were evaluated using a light microscope Leica (Germany) and computer program Image Scope Color, version $\mathrm{M}$ (in 20 fields of view, $\mathrm{x} 1000$ ).

In the studied histological material of the spleen, by IHC staining and morphometry, we obtained relative numerical values (\%) of the functional areas of the spleen (white and red pulp) and populations of B- and T-cells. Then, according to the original methodology, we calculated the absolute values $(\mathrm{g})$ of the mass of functional zones and cellular elements taking into account the spleen mass (according to patents of invention: № 2535059 dated October 08 2014, № 2625036 dated July 11, 2017 , and № 2594119 dated July 19, 2016).

Statistical analysis was performed using the computer program «STATISTICA 10.0» (StatSoft, USA). To identify the significance of differences between the indicators in the compared groups, non-parametric two-sided Kruskal - Wallace, Mann - Whitney criteria were used, taking into account the Bonferroni correction in multiple comparisons. Differences were considered statistically significant at $p<0.05$. The research results are presented with an indication of the median, the lower (25\%), and upper (75\%) quartiles.
Results and Discussion. An observation of the $B$-lymphoid population in the spleen of patients with AA showed that $\mathrm{CD}^{2} \mathrm{O}^{+}$cells were located mainly in the $\mathrm{B}$-cell zones of White Pulp (WP): in the Marginal Zone (MZ) and Lymphoid Nodules (LN). These cellular elements were localized discretely and in small perivascular clusters in the Red Pulp (RP).

As a result of morphometric research studies of the content of $B$ cells in the spleen of patients with $A A$, an increase in the number of $\mathrm{CD}_{2} 0^{+}$cells in relative values (\%) was noted, both in nSAA and SAA of the disease with respect to the control group, $\mathrm{p}<0.05$ (Table 1 ). At the same time, the dependence of changes in absolute values $(\mathrm{g})$ of the content of B-lymphocytes on the severity of the disease was revealed. In patients with SAA, a more significant number of these cells were observed for those in the group with nSAA and the control group $(p<0.05)$.

The content of $\mathrm{CD}^{+} \mathrm{O}^{+}$cells in the spleen of patients with aplastic anemia, depending on the severity of the disease

\begin{tabular}{|c|c|c|c|c|}
\hline Group & Unit & Spleen & WP & $\mathrm{RP}$ \\
\hline \multirow{2}{*}{$\begin{array}{l}\text { Control } \\
\text { group, } \\
n=20\end{array}$} & $\%$ & $\begin{array}{c}8.8 \\
(7.0 ; 10.9)\end{array}$ & $\begin{array}{c}47.1 \\
(34.3 ; 55.9)\end{array}$ & $\begin{array}{c}5.0 \\
(2.9 ; 8.4)\end{array}$ \\
\hline & $\mathrm{g}$ & $\begin{array}{c}11.2 \\
(7.5 ; 16.2)\end{array}$ & $\begin{array}{c}6.0 \\
(4.7 ; 7.2)\end{array}$ & $\begin{array}{c}4.5 \\
(2.8 ; 7.8) \\
\end{array}$ \\
\hline \multirow{2}{*}{$\begin{array}{l}\text { All } \\
\text { patients, } \\
n=30\end{array}$} & $\%$ & $\begin{array}{c}15.9 \\
(11.9 ; 18.5)^{*}\end{array}$ & $\begin{array}{c}37.1 \\
(32.8 ; 46.1) \\
\end{array}$ & $\begin{array}{c}15.2 \\
(10.6 ; 18.2)^{*}\end{array}$ \\
\hline & $\mathrm{g}$ & $\begin{array}{c}17.0 \\
(12.4 ; 22.3)^{\Delta}\end{array}$ & $\begin{array}{c}4.7 \\
(3.0 ; 6.4)^{\Delta}\end{array}$ & $\begin{array}{c}11.8 \\
(8.1 ; 17.2)^{\Delta}\end{array}$ \\
\hline \multirow{2}{*}{$\begin{array}{l}\text { nSAA, } \\
n=12\end{array}$} & $\%$ & $\begin{array}{c}15.6 \\
(9.5 ; 17.4)^{*} \\
\end{array}$ & $\begin{array}{l}40.5(30.0 ; \\
46.8)\end{array}$ & $\begin{array}{c}13.6 \\
(9.9 ; 16.3)^{*}\end{array}$ \\
\hline & $\mathrm{g}$ & $\begin{array}{c}13.5 \\
(9.0 ; 19.3)^{\bullet} \\
\end{array}$ & $\begin{array}{c}2.9 \\
(1.9 ; 4.4)^{\Delta \bullet}\end{array}$ & $\begin{array}{c}10.6 \\
(6.9 ; 12.0)^{\Delta}\end{array}$ \\
\hline \multirow{2}{*}{$\begin{array}{l}\text { SAA, } \\
n=18\end{array}$} & $\%$ & $\begin{array}{c}15.9 \\
(12.9 ; 18.4)^{*}\end{array}$ & $\begin{array}{c}36.3 \\
(32.8 ; 43.9) \\
\end{array}$ & $\begin{array}{c}16.2 \\
(12.6 ; 18.8)^{*}\end{array}$ \\
\hline & $\mathrm{g}$ & $\begin{array}{c}20.6 \\
(16.2 ; 24.9)^{\Delta}\end{array}$ & $\begin{array}{c}5.5 \\
(4.1 ; 7.0)^{\bullet}\end{array}$ & $\begin{array}{c}15.1 \\
(11.3 ; 18.4)^{\Delta}\end{array}$ \\
\hline
\end{tabular}

Note: * - a statistically significant difference concerning the control group in relative values, $\mathrm{p}<0.05 ; \Delta$ - statistically significant difference to the control group in absolute values, $p<0.05 ; \bullet-$ statistically significant difference between groups of nSAA and SAA in absolute values, $p<0.05$.

When studying the content of $\mathrm{CD} 20^{+} \mathrm{B}$-cells in the functional areas of the spleen, a statistically significant decrease in their number in WP in absolute values was revealed, mainly in individuals with nSAA with the control group and patients with SAA $(p<0.05)$. An increase in the percentage and absolute content of B-cells in RP in all patients with $\mathrm{AA}$ relative to the control group (regardless of the severity of the disease) indicates a redistribution of this population of cells in the process of the disease in the organ's RP.

In a morphological study of the distribution of T-lymphoid elements in the spleen, it was found that the total population of $\mathrm{CD}^{+}$T-cells in WP was determined mainly in periarteriolar lymphoid sheaths (PALS), as well as in a smaller amount in $\mathrm{MZ}$ and $\mathrm{LN}$. In organ's RP, $\mathrm{CD}^{+} \mathrm{T}$-cells were discretely distributed. Analysis of the content of T cells in the spleen in all patients with hematopoietic depression found that the relative values of this cell population are increased, regardless of the severity of the disease, and due to an increase in these cells in RP. At the same time, there was a decrease in the number of $\mathrm{CD}^{+} \mathrm{T}$-cells in absolute terms in WP in patients with both nSAA and SAA $(p<0.05)$.

When assessing the subpopulation composition of $\mathrm{T}$-cells, a decrease in $\mathrm{CD} 4^{+} \mathrm{T}$-cells was found in all patients with hematopoietic depression, both in absolute and 
relative values with the control group, and this was mainly due to a decrease in RP. There was a statistically significant decrease $\mathrm{CD}^{+} \mathrm{T}$-cells in only absolute values in WP (Table 2 ). Analysis of the content of $C D 4^{+} \mathrm{T}$-cells in the spleen in patients with $A A$, depending on the severity, established lower values for SAA in comparison with control group in relative and absolute numbers, mainly in RP. In patients with nSAA, a decrease in $\mathrm{CD}^{+}{ }^{+}$cells was detected concerning the control group in WP and RP in total numbers.

Table 2

The content of CD4 ${ }^{+} \mathrm{T}$-cells in the spleen of patients with aplastic anemia, depending on the severity of the disease

\begin{tabular}{|l|c|c|c|c|}
\hline \multicolumn{1}{|c|}{ Group } & Unit & Spleen & WP & RP \\
\hline $\begin{array}{l}\text { Control } \\
\text { group, } \\
\text { n=20 }\end{array}$ & $\%$ & $5.5(4.2 ; 7.4)$ & $\begin{array}{c}12.5 \\
(9.1 ; 16.6)\end{array}$ & $4.6(4.0 ; 6 ; 8)$ \\
\cline { 2 - 5 } & $\mathrm{g}$ & $6.7(4.8 ; 9.4)$ & $1.6(1.2 ; 2.8)$ & $4.9(3.2 ; 6.2)$ \\
\hline $\begin{array}{l}\text { All } \\
\text { patients, } \\
\text { n=30 }\end{array}$ & $\%$ & $\begin{array}{c}4.0 \\
(3.0 ; 5.3)^{*}\end{array}$ & $\begin{array}{c}13.5 \\
(7.0 ; 17.6)\end{array}$ & $\begin{array}{c}3.3 \\
(2.7 ; 5.0)^{*}\end{array}$ \\
\cline { 2 - 5 } $\begin{array}{l}\text { nSAA, } \\
\text { n=12 }\end{array}$ & g & $4.6(3.5 ; 5.4)^{\Delta}$ & $1.4(0.6 ; 2.0)^{\Delta}$ & $3.4(2.0 ; 4.5)^{\Delta}$ \\
\cline { 2 - 5 } & $\mathrm{g}$ & $4.2(3.5 ; 5.3) \Delta$ & $1.2(0.4 ; 2.0) \Delta$ & $3.5(1.5 ; 4.1)^{\Delta}$ \\
\hline \multirow{2}{*}{$\begin{array}{l}\text { SAA, } \\
\text { n=18 }\end{array}$} & $\%$ & $3.3(2.7 ; 4.9)^{*}$ & $9.7(5.9 ; 13.9)$ & $3.3(2.5 ; 5.0)^{*}$ \\
\cline { 2 - 5 } & $\mathrm{g}$ & $4.7(3.6 ; 5.5) \Delta$ & $1.4(0.7 ; 2.2)$ & $3.2(2.3 ; 5.0)^{\Delta}$ \\
\hline
\end{tabular}

Note: * - a statistically significant difference concerning the control group in relative values, $p<0.05 ; \Delta$ - statistically significant difference to the control group in absolute values, $\mathrm{p}<0.05$

Based on morphometric research studies, it was found that when the mass of $\mathrm{CD}^{+} \mathrm{T}$-cells in the spleen was more than or equal to $5.4 \mathrm{~g}$, a favorable course of aplastic anemia was observed, and at absolute values less than $5.4 \mathrm{~g}$, a poor prognosis of the disease was revealed (Method for predicting the course of aplastic anemia after splenectomy by weight of spleen $\mathrm{CD} 4^{+} \mathrm{T}$-cells: patent for invention № 2625036 dated July 11, 2017).

In the research study of a subpopulation of $\mathrm{CD}^{+}$ cytotoxic T-cells in the spleen of patients with $A A$, it was noted that they were located both in WP and in RP. The number of these cells in the spleen was significantly increased in all AA patients with respect to the control group $(p<0.05)$, both in relative and absolute values (Table 3 ). The increase in the number of CD8 ${ }^{+}$cells was determined mainly in the organ's RP and did not depend on the severity of the disease.

Calculation of the Mass Ratio Index (MRI) of $\mathrm{CD}^{+} /$ $\mathrm{CD}^{+} \mathrm{T}$-cells made it possible to establish a prognosis factor of the disease for which a favorable course of AA was observed for values $>1.0$, and an unfavorable course for $\mathrm{MRI} \leq 1.0$ (Method for predicting the course of aplastic anemia after splenectomy by the mass ratio index of $\mathrm{CD}^{+} / \mathrm{CD} 8^{+} \mathrm{T}$-cells of the spleen: invention patent № 2594119 dated July 19 2016).

Table 3

The content of $\mathrm{CD}^{+} \mathrm{T}$-cells in the spleen of patients with aplastic anemia, depending on the severity of the disease

\begin{tabular}{|c|c|c|c|c|}
\hline Group & Unit & Spleen & WP & RP \\
\hline \multirow{2}{*}{$\begin{array}{l}\text { Control } \\
\text { group, } \\
n=20\end{array}$} & $\%$ & $0.5(0.3 ; 0.9)$ & $0(0 ; 0.6)$ & $0.4(0.3 ; 0.7)$ \\
\hline & $g$ & $0.6(0$ & $0(0 ; 0.7)$ & $.4(0.3 ; 0.6)$ \\
\hline \multirow{2}{*}{$\begin{array}{l}\text { All } \\
\text { patients, } \\
\mathrm{n}=30\end{array}$} & $\%$ & $3.7(3.0 ; 4.2) *$ & $2.2(0 ; 4.8)$ & $4.6(3.8 ; 5.6)^{*}$ \\
\hline & g & $4.0(2.8 ; 4.8)^{\Delta}$ & $0.3(0 ; 0.5)$ & $3.6(2.8 ; 4.7)^{\Delta}$ \\
\hline \multirow{2}{*}{$\begin{array}{l}\text { nSAA, } \\
n=12\end{array}$} & $\%$ & $3.7(3.3 ; 4.2) *$ & $2.7(0 ; 5.0)$ & $4.6(4.1 ; 5.3)^{*}$ \\
\hline & $\mathrm{g}$ & $4.0(3.1 ; 5.1)^{\Delta}$ & $0.1(0 ; 0.7)$ & $3.6(3.0 ; 4.9)^{\Delta}$ \\
\hline \multirow{2}{*}{$\begin{array}{l}\text { SAA, } \\
\mathrm{n}=18\end{array}$} & $\%$ & $3.6(2.6 ; 4.2) *$ & $2.2(0 ; 4.2)$ & $4.6(3.2 ; 5.6)^{*}$ \\
\hline & $\mathrm{g}$ & $4.2(2.5 ; 4.9)^{\Delta}$ & $0.3(0 ; 0.5)$ & $3.7(2.8 ; 4.8)^{\Delta}$ \\
\hline
\end{tabular}

Note: * - a statistically significant difference concerning the control group in relative values, $\mathrm{p}<0.05 ; \Delta$ - statistically significant difference to the control group in absolute values, $\mathrm{p}<0.05$.

There are reports $[4,5,6]$ on the studies of the functional heterogeneity of $\mathrm{CD}^{+}{ }^{+}$T-cells and the effect of this subpopulation on bone marrow hematopoiesis in AA. It was shown that a decrease in the content of regulatory $\mathrm{CD} 4^{+} \mathrm{CD} 25^{+}$ T-cells in the peripheral blood and bone marrow contributes to the failure of hematopoiesis in AA due to a violation of the inhibition of the production of INF- $\gamma$ synthesized by effector T cells by these cells [6]. Also, the revealed decreases and functional disorders of regulatory T-cells in patients with AA were identified mainly in patients with a severe form of the disease [4]. The effect of cytotoxic $\mathrm{CD}^{+} \mathrm{T}$-cells on the development of hematopoiesis due to the release of immune aggression mediators (INF- $\gamma, \mathrm{TNF}-\alpha$ ) is described in the literature $[1,2,7]$. It is also known that effector T-cells $\left(C D 8^{+}\right)$ can suppress regulatory T-cells [4]. The data obtained as a result of our work on the increase in the content of cytotoxic $\mathrm{CD}^{+} \mathrm{T}$-cells in RP, and the assessment of the interaction of $\mathrm{CD}^{+}$and $\mathrm{CD} 8^{+}$T-cells in the spleen of patients with AA significantly complement and contribute to a deeper understanding of the immune mechanisms of the disease.

We did not find data on the content of B cells in the spleen with $A A$ in the available literature, and therefore our new data obtained by us on the distribution of $\mathrm{CD}^{2} \mathrm{O}^{+}$cells in the pulp of an organ, depending on the severity of the disease, is a crucial information indicating the participation of this cell population in the pathogenesis of the disease.

Conclusions. The data obtained for the first time on the content of B- and T-cells in the spleen of patients with nSAA and SAA substantiate an individual approach to further courses of immunosuppressive therapy in this category of patients after splenectomy.

Disclosures:

The authors declare no conflict of interest.

\section{References}

1. Lin F., Karwan M., Saleh B., Hodge D. L., Chan T. [et al.] IFN-y causes aplastic anemia by altering hematopoietic stem/progenitor cell composition and disrupting lineage differentiation. Blood. 2014;124(25):3699-3708. https://doi org/10 1182/blood-2014-01-549527

2. Bruin A. M., Demirel O., Hooibrink B., Brandts C. H., Nolte M. A. Interferon-y impairs proliferation of hematopoietic stem cells in mice. Blood. 2013;121(18):3578-3585. https://doi.org/10.1182/blood-2012-05-432906

3. Mikhailova E. A., Savchenko V. G., Ustinova E. N., Vinogradova M. A., Kokhno A. V. [et al.] Splenectomy in programmed therapy for aplastic anemia. Terapevticheskiy arkhiv. - Therapeutic Archive. 2006;78(8):52-57.

4. Kordasti S. Costantini B. Seidl T., Abellan P. P., Llordella M. M. [et al.] Deep phenotyping of Tregs identifies an immune signature for idiopathic aplastic anemia and predicts response to treatment. Blood. 2016; 128 (9):1193-1205. https://doi.org/10.1182/blood-2016-03-703702

5. Latour R. P., Visconte V. , Takaku T., Wu C., Erie A. J. [et al.] Th17 immune responses contribute to the pathophysiology of aplastic anemia. Blood. 2010;116(20):4175-4184. https://doi.org/10.1182/blood-2010-01-266098

6. Shi J., Ge M., Lu S., Li X., Shao Y., Huang J. [et al.] Intrinsic impairment of $\mathrm{CD} 4^{+} \mathrm{CD} 25^{+}$regulatory T-cells in acquired aplastic anemia. Blood. 2012;120(8):1624-1632 https://doi.org/10.1182/blood-2011-11-390708

7. Ren J. Hou X. Y, Ma S. H., Zhang F. K. Zhen J. H. [et al.] Elevated expression of $\mathrm{CX} 3 \mathrm{C}$ chemokine receptor 1 mediates recruitment of $T$ cells into bone marrow of patients with acquired aplastic anemia Journal of Internal Medicine. 2014;276(5):512-524. https://doi.org/10.1111/joim.12218 


\section{About authors:}

Fedorovskaya Nadezhda Stanislavovna, PhD (medical science), Associate Professor of the Department of pathological anatomy; tel.: +79128245918; e-mail: fednadst@mail.ru

Petrov Semen Venediktovich, MD, Professor, Professor of the Department of general pathology; tel.: +79172737581; e-mail: semyonp@mail.ru

Zaitsev Valery Borisovich, MD, Professor, Professor of the Department of histology, embryology and cytology; tel.: +78332678801; e-mail: kf7@kirovgma.ru

(c) Group of authors, 2019

UDC 615.272.4

DOI - https://doi.org/10.14300/mnnc.2019.14107

ISSN - 2073-8137

\section{THE LIPID-LOWERING TREATMENT AFTER ACUTE CORONARY SYNDROME IN THE REAL CLINICAL PRACTICE: POSSIBLE ROLE OF THE PHARMACOGENETIC INTERACTIONS}

Brazhnik V. A. ${ }^{1,2}$, Minushkina L. O. ${ }^{2}$, Rogozhina A. A. ${ }^{2}$, Averkova A. O. ${ }^{3}$, Zubova E. A. ${ }^{1}$ Koroleva O. S. ${ }^{2}$, Chichkova M. A. ${ }^{4}$, Khasanov N. R. ${ }^{5}$, Kosmacheva E. D. ${ }^{6}$, Boyeva O. I. ${ }^{7}$, Speshilov G. I. 8, 9 , Guliev R. R. ${ }^{10}$, Zateyshchikov D. A. ${ }^{1,2}$

1 City clinical hospital № 51, Moscow, Russian Federation

2 Central State Medical Academy, Moscow, Russian Federation

3 M. V. Lomonosov Moscow State University, Russian Federation

${ }^{4}$ City clinical hospital № 17, Moscow, Russian Federation

5 Kazan State Medical University, Russian Federation

${ }^{6}$ Kuban State Medical University, Krasnodar, Russian Federation

7 Stavropol State Medical University, Russian Federation

8 A. A. Kharkevich Institute for Information Transmission Problems of Russian Academy of Sciences, Moscow, Russian Federation

9 "Ridsens» Ltd, Troitsk, Moscow, Russian Federation

${ }^{10}$ N. M. Emanuel Institute of Biochemical Physics of the Russian Academy of Sciences, Moscow, Russian Federation

\section{ГИПОАИПИАЕМИЧЕСКАЯ ТЕРАПИЯ У БОАЬНЫХ С ОСТРЫМ КОРОНАРНЫМ СИНАРОМОМ В РЕААЬНОЙ КАИНИЧЕСКОЙ ПРАКТИКЕ: ВОЗМОЖНАЯ РОАЬ ФАРМАКОГЕНЕТИЧЕСКИХ ВЗАИМОАЕЙСТВИЙ}

В. А. Бражник ${ }^{1,2}$, А. О. Минушкина ${ }^{2}$, А. А. Рогожина ${ }^{1,2}$, А. О. Аверкова ${ }^{3}$, Е. А. Зубова ${ }^{1}$, О. С. Королева ${ }^{2}$, М. А. Чичкова ${ }^{2,4}$, Н. Р. Хасанов ${ }^{5}$, Е. А. Космачева ${ }^{6}$, О. И. Боева ${ }^{7}$, Г. И. Спешилов ${ }^{8,9}$, Р. Р. Гулиев ${ }^{10}$, А. А. Затейщиков ${ }^{1,2}$

1 Городская кАиническая больница № 51, Москва, Российская ФеАерация

2 Центральная госуАарственная меАицинская акаАемия, Москва, Российская ФеАерация

3 Московский госуаарственный университет им. М. В. Аомоносова, Российская ФеАерация

4 Городская кАиническая больница № 17, Москва, Российская ФеАерация

${ }^{5}$ Казанский госуАарственный МеАицинский университет, Российская ФеАерация

${ }^{6}$ Кубанский госУАарственнЫЙ МеАицинскиЙ Университет, КрасноАар, Российская ФеАерация

7 Ставропольский госуАарственный меАицинский университет, Российская ФеАерация

8 Институт проблем передачи информации им. А. А. Харкевича Российской акаАемии наук, Москва, Российская ФеАерация

9 ООО «РиАсенсІ, Троицк, Москва, Российская ФеАерация

10 Институт биохимической физики им. Н. М. Эмануэля Российской акаАемии наук, Москва, Российская Фелерация

The study aimed to assess the possibility of individualizing lipid-lowering therapy in patients after acute coronary syndrome (ACS). The study included 1408 patients from the ORACUL II study, who has undergone ACS for the first time (60.5\% of men, average age $65.18 \pm 12.81$ years), discharged from the hospital. Statins were prescribed to 1315 (93.4\%) patients at 